\title{
パーキンソン病治療薬の問題点と今後望まれる薬剂
}

\section{村田 美穂}

要約：パーキンソン病 $(\mathrm{PD})$ は大脳黒質ドパミンニ ユーロンの変性により振戦，無動，固縮，姿勢調節障 害を主体とする，アルッハイマー病に次いで多い神経 変性疾患である．抗 PD 薬はドパミン前駆物質である L-dopa を始めドパミン受容体刺激薬, MAO 阻害薬, COMT 阻害薬等多数開発されているが, 現時点では L-dopa をしのぐ薬剤はない. L-dopa は効果が高く, 副作用は少なく廉価で極めて優れた薬剤であるが，半 減期が短いのが最大の欠点である.PD 治療において は現存の薬剤で初期には良好な効果を得られるが, 長 期治療中には効果持続時間の短縮により wearing-off 現象や不随意運動, 精神症状などの問題点が出現して くる. 今後期待される薬片としては, 半減期の長い L-dopa 製片, 振戦, すくみ, 姿勢調節障害に効果の 高い薬剂, さらに, 細胞変性を $50 \%$ 程度で維持でき る神経保護薬の開発が強く望まれる。

\section{1. パーキンソン病とは (1)}

パーキンソン病（PD）は大脳黒質ドパミンニュー ロンの選択的変性によりおこる神経変性疾患である. 通常 40 歳代以上で発症する孤発性の疾患であるが, 10 歳未満の若年発症もありうる. 平均発症年齢は 60 歳台であるが, L-dopa 製剤の開発以後, 生命予後は 格段に改善しほほ健常者とかわらないため, 加齢とと もに患者数は増加し, 現在の有病率は人口 10 万人あ たり 150 人程度, 70 歳以上では $1 \%$ 近いとされている.

臨床症状は振戦, 固縮, 無動を三大徵候, さらに姿 勢調節障害を含めて 4 大徵候と呼んでいる，姿勢調節 障害は中等度以上の重症度の場合に認める症状で,

PD では初期からこれが前面に立つことはない，実際 の生活では歩行障害や, 日常生活動作のやりにくさ, 遅さ，バランスの悪さなどが問題になる．PDではこ
れらの運動症状のほかに便秘, 脂顔, 起立性低血圧な どの自律神経障害や, 抑うつなど精神症状も伴うこと が多い. 多数の抗パーキンソン病薬の開発により運動 症状はかなり改善してきたこともあり, 最近はこれら の非運動症状も注目されている.

\section{2. パーキンソン病の治療と長期治療上の問題点}

パーキンソン病における黒質神経細胞の減少は図 1 （2）のように初期により速く，進行に伴い緩徐になる ことが知られている. 治療初期の $3-5$ 年ぐらいは現存 の抗 PD 薬を十分量使用することでかなりよい効果を 得られることが多い.その後ドパミン神経細胞が 50-70\% 程度障害されると, wearing-off 現象や不随意 運動が出現しやすくなる(3). Wearing-off 現象とは L-dopa の効果持続時間が短縮し, 1 日 3-4 回 L-dopa

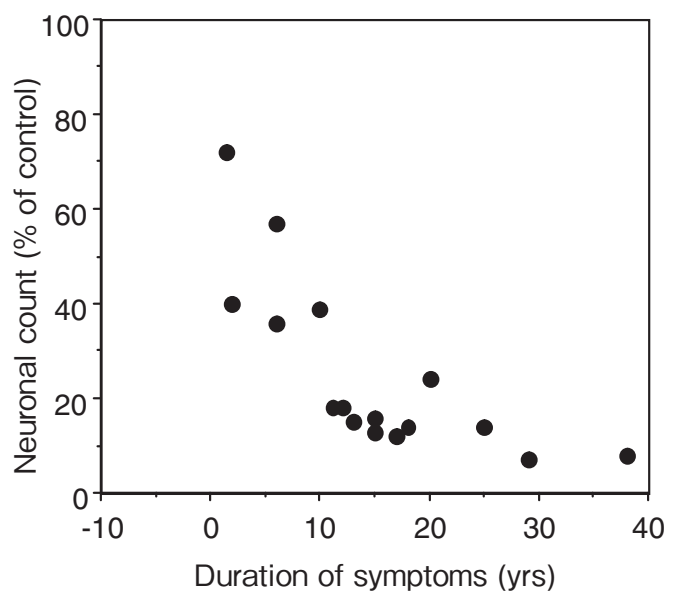

図 1 パーキンソン病の罹患期間と年齢補正した残存黒質ド パミン神経細胞数

正常黒質ドパミン細胞数を $100 \%$ としている．発症時すでに 70\% 程度に減少していると考えられている. これらの病理学的検討や PET の結果から, 発症までに 7 年程度経過していると考えられて いる. (文献 2 より一部改変)

キーワード : L-dopa, wearing-off 現象, 細胞保檴薬

国立精神・神経センター武蔵病院神経内科（テ187-8551 東京都小平市小川東町 4-1-1）

e-mail: mihom@ncnp.go.jp＼cjkstart原稿受領日：2008 年 1 月 26 日, 依頼原稿

Title: The development of therapeutic agents for Parkinson's disease and problems in their clinical application.

Author: Miho Murata 


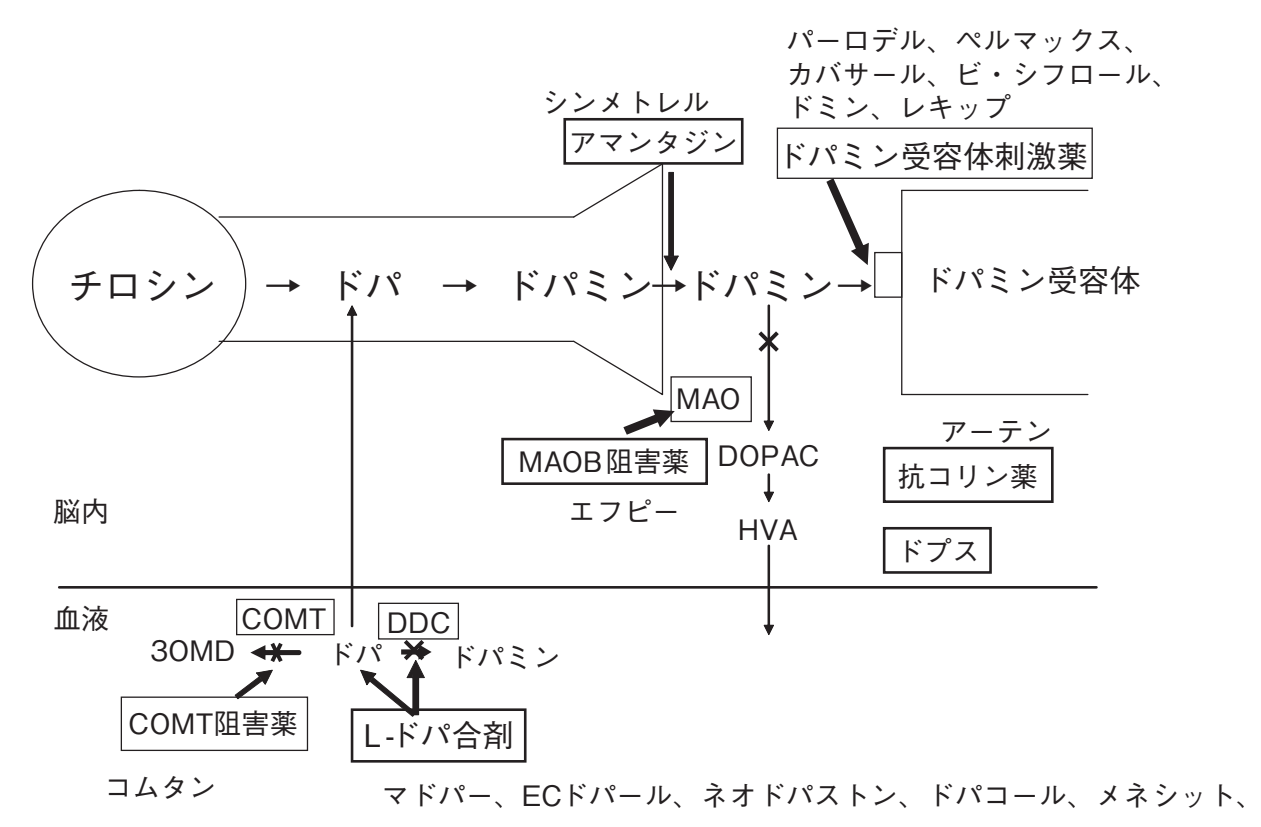

図 2 主な抗パーキンソン病薬とその作用点

を服用してもなお，L-dopa の血中濃度の変化に伴い 症状が変動することをいう。これは原疾患の進行によ りドパミン神経終末が減少するとドパミン保持能が低 下し，シナプス間隙でのドパミン動態は血中 L-dopa 動態とほぼ同様となることと, L-dopa の半隇期が約 1 時間と短いことが主な原因である。若年発症者では 極めて出現しやすく, 高齢発症者では L-dopa の血中 動態が比較的緩徐であるためか, 出現しにくい. 不随 意運動はドパミン刺激が非常に強ければ正常なドパミ ン系でも出現しうるが, ドパミン神経終末の減少が高 度であるほど出現しやすい。これも若年発症者では出 現しやすく, 軽度であればあまり問題にならないが, 高度になると日常生活の阻害因子になる。この時期ご ろから, 姿勢調節障害や, すく久現象などが出現し, 日常生活の障害が大きくなることも多い. 60 歳未満 発症では, 臨床症状はまさにドパミン欠乏により起こ るものが主体であるので， ドパミン刺激が過不足なく 脳内に到達するように調節して投薬することでかなり 高い効果を得られる. しかし, 高齢発症者では, ドパ ミン久乏以外に, 加齢に伴う運動能力の低下や骨, 関 節系の障害などが加わり, 抗 PD 薬の効果はやや低い ことが多い，また，高齢者では加齢に伴う，認知症な どの合併も多く, 認知症の合併は幻覚, 妄想などを引 き起こしやすくなり, 抗 PD 薬を十分量投与すること の阻害因子となりやすい.

\section{3. 既存の抗 PD 薬とその特徵}

既存の主な抗 PD 薬とその作用点を図 2 に示した.

\section{1) L-dopa 製剤}

多くの薬剤が開発されているが, 現時点でも L-dopa に勝る薬剤はない。一時期, ドパミンおよび L-dopa の神経毒性が問題になったが, 現時点では L-dopa が 臨床的に問題になる毒性を持つというエビデンスはな く(4)，それどころか ELLDOPA study(5) は，早期に L-dopa で治療することにより（1 年間の継続投与の 後）投薬中止 2 週間後（L-dopa の半減期は 1 時間程 度である）でも未治療患者より症状がよいことから， L-dopa は神経保護作用をもつという解釈もある. L-dopa は効果が高く, 副作用も少なく, 廉価で極め て優れた薬荗であるが, 半減期が短いことが最大の欠 点である. 効果がはっきりしていて半眼期が短いため に wearing-off 現象がわかるといっても過言ではない. また特に食前服用の大量投与により，L-dopa は急峻 な血中動態を示し(6), 過剩なドパミン刺激により不 随意運動を出現しやすい.

\section{2) ドパミン受容体刺激薬}

L-dopa の大量投与により wearing-off や不随意運 動が問題になり，これらの問題点を解決するために多 くのドパミン受容体刺激薬（以下アゴニストと略す） が開発された. 現在わが国では 6 種類のアゴニスト (ブ ロモクリプチン, ペルゴリド, カベルゴリン, プラミ ペキソール，タリペキソール，ロピニロール）が使用 可能であるが, 開発の時代背景によりエビデンスの有 無に多少違いはあるが, 統計学的に有意な効果の差は ないとされている(7).

アゴニストの半減期は 6-42 時間と薬剂により様々 
であるが，いずれも L-dopaに比較するとより緩徐な 動態を示し, 効果が持続しやすいことが最大の利点で ある. 一方抗 PD 効果はやや弱く, パーキンソン病の 重症度の Yahr 2 までであればアゴニストは増量によ り L-dopa と同等の効果を得られるが，Yahr 2.5 以上 （中等症以上）では L-dopa に匹敵する効果をアゴニ スト単独で得ることはできない(8)。したがって，ア ゴニストで治療を開始しても疾患の進行に伴い必ず L-dopa と併用する必要がある.

副作用は L-dopaよりも頻度が多い. 吐き気, 便秘 などの消化器症状, 動悸などは末梢のドパミン受容体 への作用と考えられる. 幻覚は中枢性のドパミン刺激 作用と考えられるが，アゴニストは L-dopaに比較す ると運動系への作用が弱いにもかかわらず幻覚の頻度 は高いことが知られている(9).

アゴニストはその構造により麦角剤と非麦角剂に分 類される. 麦角剂では以前より後腹膜紼維症や胸膜炎 などが起こりうることが言われていたが, 最近ペルゴ リドとカベルゴリンについては心臓弁の逆流を起こす 頻度が高いことが問題になっている(10). セロトニン $5 \mathrm{HT}_{2 \mathrm{~B}}$ 受容体へのアゴニスト作用が関係するとされ, 麦角剂でもブロモクリプチンでは頻度は極めて低い. ただしこれら 2 剂では確かに弁逆流の頻度は高いもの の, 臨床的に問題になるケースは極めて少ない. した がって直ちに使用を中止する必要はないが, 1 年に 1-2 回心エコー等でチェックすることと, 第 1 選択にすべ きではないことが神経学会からも通達されている(11). 一方, 眠気についてはどの抗 PD 薬にもあるとされ, 薬剤による統計学的な有意差はないとされているが, 現場の印象では非麦角剤のプラミペキソール, タリペ キソール，ロピニロールは眠気特に睡眠発作とも呼ば れる急激な眠り込み（コーヒーを飲んでいて眠ってし まうなど）の頻度がかなり高い. 自動車運転などは警 告事項になっているが, 実際には自動車が使えなけれ ば通院もできない地域も少なくなく, 日常生活にはむ しろこちらのほうが問題が大きいとも言える.

\section{3) モノアミン酸化酵酵素 (MAO) B 阻害薬,}

\section{カテコール o メチル転移酵素 (COMT) 阻害薬}

いずれも L-dopa と併用し, MAOB 阻害薬（わが国 ではセレギリンのみ）は脳内でドパミン代謝を抑制し， COMT 阻害薬 (エンタカポン) は末梢で L-dopa 合剤 (脱炭酸酵素阻害薬との合剤) 投与時の L-dopa の代 謝を抑制し， L-dopa の欠点である効果の持続時間短 縮を改善する，つまり wearing-off 現象を改善するた めの薬剤である.MAOB 阻害薬は内因性のドパミン の代謝も抑制するので初期に単独で使う価值はあるが,
わが国では L-dopa との併用のみが認められている. セレギリンは神経保護作用も期待されるが現時点で臨 床的なエビデンスはまだない.

セレギリンはドパミン刺激を大きくするため, 効果 持続時間が延長するとともに, 場合によっては不随意 運動を発現あるいは増強する可能性がある。また, MAOB 阻害薬であることから, 抗うつ薬との併用が 制限されているのが難点である.

エンタカポンは単回投与では L-dopa の Cmax は上 昇させずに $\mathrm{T}_{1 / 2}$ だけを延長させることになっている が, L-dopa と同時に 1 日数回服用するため, 夕イミ ングにより L-dopa の Cmax も上昇し, 不随意運動が 増強してしまうこともある(12).

\section{4. 今後望まれる薬剤}

現在, 多数の抗 PD 薬があるが, L-dopaに勝る薬 剂はまだない。最も望まれるのは, 半減期の長い L-dopaである. L-dopa は切れ味の良いことが身上で あるので, Tmax が長いと患者満足度が低く, Tmax が短く, かつ半減期が長い薬剤が望まれる。 日中と夜 間は生理的なドパミン必要量が異なると考えられ，24 時間同量の L-dopa を投与すると効果出現閾值が上昇 するため (13) に, L-dopa 持続投与（腸管内投与など） は 1 日 12-16 時間持続投与とされている $(13,14)$. こ れを考慮すると $\mathrm{T}_{1 / 2}$ が 24 時間以上あることはむしろ 不要で 6-7 時間であれば十分であり, たとえば貼付薬 で夜間は剥がす，あるいは容量を少なくするなどの調 節ができるものが望まれる。

ドパミン神経の変性が50-60\%程度で維持できれば 現存の薬剤でかなりコントロール可能であると考えら れることから, 新たな薬剤を考える上で, ターゲット とすべき症状と神経保護の 2 点に分けて次に述べる.

\section{1) 症状に対し}

L-dopa は固縮, 無動に高い効果を示すが, 振戦に はやや効果が低い。 また, 姿勢調節障害やすくみ現象 は L-dopa 反応性の場合もあるが, L-dopaに不応性の 場合も少なくない. 振戦については抗コリン薬が比較 的効果が高いが最近認知症との関連でとくに高齢者で は使いにくくなっている．筆者が抗 PD 作用を発見し， 現在, 抗 PD 薬として申請中のゾニサミドはドパミン 系を介す作用と介さない作用の 2 つの作用により振戦 に対し比較的高い効果を示す $(15,16)$.

すくみ現象はコントロール困難な臨床上極めて重要 な症状であるが, 現存の抗 PD 薬の効果は少ない. ド プスはノルアドレナリンの前駆体で，すくみ現象に対 する効果を期待されて開発された薬片であるが, 高い 
効果が得られる頻度は少ない. ターゲットとする症状 としてはこの振戦とすくみ現象があげられる。

PD に伴う精神症状に対する薬剤は抗 PD 薬ではな いが今後運動症状に対する治療が向上するにつれ，ま すます重大な問題になっていくと思われるので, 簡単 に触れる.PDに伴う精神症状としては, 抑うつ症状と, 抗 PD 薬と認知障害によると思われる幻覚, 妄想が主 なものである．抑うつ症状はいわゆる大うつ病はまれ であるが，抑うつ的な患者の頻度は高く，これにより， 抗 PD 薬の効果が半減, あるいは効果不十分と考えて 抗 PD 薬を増量することにより薬物性の幻覚を引き起 こすほど過量投与になってしまう場合もあり, 治療上 の大きな問題である. 薬物開発という点から考えると PD に特異的な抗うつ薬というよりは神経内科医が抗 うつ薬の使い方により通暁することでかなり解決する 問題かもしれない, 一方, 幻覚, 妄想は, 患者の高齢 化に伴い, また以前より多くの抗 PD 薬を使うょうに なったこと, それに伴い運動症状はより改善したこと などから，ょり大きな問題になってきている. クエチ アピンなど非定型向精神薬の開発により, 以前よりは 治療しやすくなったものの, やはり治療に苦慮してい る，また同様に PD に伴う認知症あるいはレビー小体 型認知症に対する治療薬の開発も強く期待される.

\section{2）細胞変性に対し}

胎児黒質細胞移植の結果が期待されたものではなか った（17）ことを考慮すると，脳内でネットワークが 構築できていないドパミン産生細胞の移植の効果は L-dopa 服用とあまり大きな差はないことがわかる. 薬の服用というわずらわしさはあるものの, 必要に応 じてドパミン量をある程度調節できる点ではむしろ
L-dopa のほうが勝っているとさえいえる. 一方で, 上に述べたようにドパミン残存細胞が 40-50\%あれば 現存の薬剤のみでもかなりよい治療効果を得られる. 細胞変性を多少抑制する, あるいは遅くすることがで きれば，PDの長期治療効果は飛躍的に改善できると いえよう。詳細は基礎編で述べられていると思うが, ドパミン神経細胞死のメカニズムとして, 小胞体やミ トコンドリアの機能障害が明らかになってきており, これらに対する薬剂, あるいは神経細胞の機能維持に 重要な役割を担っているグリアの機能を修飾する薬剤 などがこの細胞変性を遅らせる薬剤として有望であろ う.

現時点では臨床的に神経保護作用を評価する方法論 が確立していないため, 薬として世にだすことはかな り難しいという側面はあるが, 今後この方面での研究 の発展が強く期待される.

\section{文献}

1)「脳の科学」編集委員会. パーキンソン病のすべて. 脳の科 学増刊. 2004.

2) Fearnley JM, et al. Brain. 1991;114:2283-2301.

3) Jenner P, et al. Mov Disord. 2006;21 Suppl 13:S73.

4) Suchowersky O, et al. Neurology 2006;66:976-982.

5) The Parkinson Study Group. NEJM. 2004;351:2498-2508.

6) 村田美穂. 内科. 1999;83:491-493.

7) Pahwa R, et al. Neurology. 2006:66:983-995.

8) Rascol O, et al. Mov Disord. 1998;13:39-45.

9) Miyasaki JM, et al. Neurology. 2002;58:11-17.

10) Antonini A, et al. Lancet Neurol. 2007;6:826-829.

11）葛原茂樹. 臨床神経 . 2007;47:687-688.

12) Mizuno Y, et al. Mov Disord. 2007;22:75-80.

13) Cedarbaum JM, et al. Neurology. 1990;40:995-997.

14) Stocchi F, et al. Arch neurol. 2005;62:905-910.

15) Murata M, et al. Neurology. 2007;68:45-50.

16) Miwa H, et al. Parkinsonism Relat Disord. 2007 Jun 21(Epub ahead).

17) Olanow CW, et al. Ann Neurol. 2003;54:403-414. 